Eur. J. Clin. Chem. Clin. Bíochem.

Vol. 32, 1994, pp. 119-121

(c) 1994 Walter de Gruyter \& Co.

Berlin - New York

\title{
The Kinetics of Aluminium-Containing Antacid Absorption in Man
}

\author{
By E. Nagy and K. Jobst \\ Pécsi Orvostudományi Egyetem, Klinikai Kémiai Intézet, Pécs, Hungary
}

(Received May 24/December 7, 1993)

Summary: The kinetics of aluminium absorption were determined in patients with duodenal ulcer and in 2 normal males after taking the antacid Tisacid (Biogal, Hungary). A peak serum aluminium of $54.5 \mu \mathrm{g} / \mathrm{l}$ was reached at $30 \mathrm{~min}$, returning to the initial value of $6.8 \mu \mathrm{g} / \mathrm{l}$ at $3 \mathrm{~h}$ after the oral intake. Urinary but not serum aluminium increased in parallel to the amount of drug taken. The serum Al values are considerably influenced by the time of sampling. Owing to the rapid absorption and excretion of aluminium, there appears to be no danger of aluminium deposits in the tissues or of neurological alterations, provided renal function is normal.

\section{Introduction}

Widely varying serum aluminium values are observed in ulcer patients regularly taking the aluminium-containing antacid, "Tisacid" (Biogal, Hungary). Preanalytical error was considered as a possible explanation. Since no detailed data are available on the absorption of antacids in man $(1-3)$, we carried out an experiment on ourselves, speculating that knowledge of the time course of absorption and of the time points of sampling might help to clarify the surprising differences in results.

\section{Patients and Method}

Serum and urinary concentrations of aluminium were determined in six patients with duodenal ulcer after treatment with Tisacid (formula: $\mathrm{Al}_{2} \mathrm{Mg}_{4}(\mathrm{OH})_{12} \mathrm{CO}_{3} \cdot \mathrm{tH}_{2} \mathrm{O}$ ). It is supplied in tablets, each containing $105.06 \mathrm{mg}$ magnesium, $58.1 \mathrm{mg}$ aluminium and vehicles. All patients took $4 \times 2$ tablets in $0.1 \mathrm{l}$ of tap water per day. Blood samples were generally drawn on an empty stomach prior to, and occasionally after, the administration of Tisacid.

Two experiments were conducted on the authors themselves. In the first, they took 18 tablets within $37 \mathrm{~h}$; in the first $8 \mathrm{~h}, 2$ tablets every $2 \mathrm{~h}$ and then, following a break of $16 \mathrm{~h}, 5 \times 2$ tablets at intervals of $2 \mathrm{~h}$. The serum and urinary concentration of aluminium were determined at 6,30 and $60 \mathrm{~h}$ after administration of the first tablets. In the second experiment blood was collected in a Braun cannula at $15,30,45$ and $60 \mathrm{~min}$, and then at 2,3 and $4 \mathrm{~h}$ after the ingestion of 4 tablets of Tisacid, urine being collected for $24 \mathrm{~h}$. The aluminium concentration in $1 \mathrm{~mol} / 1 \mathrm{HCl}$ extracts from stools was determined on days prior to the experiment and after the taking of Tisacid. The experiments were repeated after an interval of 14 days.

An oral tolerance test with $50 \mathrm{~g}$ glucose was performed after an aluminium loading study. The serum aluminium concentration of the glucose samples did not exceed $10 \mu \mathrm{g} / \mathrm{l}$.

The aluminium content was determined using a Varian SpektrAA.20 atomic absorption spectrometer equipped with a GTA-96 graphite tube atomizer $(4-6)$. The results of the determinations are given in $\mu \mathrm{g} / \mathrm{l}$ (factor: $0.037 \times \mu \mathrm{g} / \mathrm{l}=\mu \mathrm{mol} / \mathrm{l}$ ). Aluminium samples were collected in polypropylene vessels (BCL. Lewes, Sussex, UK), which were washed with diluted nitric acid (volume fraction 0.1 ) and rinsed with distilled deionized water before use to minimize aluminium contamination.

\section{Statistical analyses}

A reference aluminium solution $\left(, 1000 \mathrm{ppm}^{\prime \prime},=1 \mathrm{~g} / \mathrm{l}\right.$, Sigma, USA) was used to prepare fresh standard aluminium solutions daily. The calibration curve was linear with a correlation coefficient $\left(r^{2}\right)$ of 0.98 . The limit of detection was $6 \mu \mathrm{g} / \mathrm{l}$. The analytical method was validated by addition of a standard solution of $\mathrm{Al}$ (10 to $100 \mu \mathrm{g} / \mathrm{l})$ to serum. The measured aluminium concentration was linearly related to the theoretical aluminium content, with an $r^{2}$ value of 0.98 . Repeated determinations showed the coefficient of variation to be lower than $5 \%(n=7)$. There was no significant statistical difference between the data obtained from the direct and the standard addition methods ( $t$ test for paired observations gave $P>0.05)$. Sensitivity, as the quantity needed to give $1 \%$ absorption, was found to be $0.8 \mu \mathrm{g} / 1$, and for $1: 5$ diluted serum, $3.0 \mu \mathrm{g} / \mathrm{l}$. Data are presented as means \pm SD: the serum aluminium values of antacid-treated patients were $8.9 \pm 2.1 \mu \mathrm{g} / \mathrm{l}$, in the experiments on ourselves $7.7 \pm 1.5 \mu \mathrm{g} / \mathrm{l}$ aluminium. 


\section{Results}

Figure 1 presents the aluminium values for serum and urine observed in one of the 6 patients with duodenal ulcer in the course of Tisacid treatment. At serum values under $10.0 \mu \mathrm{g} / \mathrm{l}$, accepted as normal, the excretion of aluminium did not exceed the permissible concentration of $30.0 \mu \mathrm{g} / \mathrm{l}$. The serum aluminium concentration of the other 5 Tisacid-treated patients, calculated from 34 serum samples, was $8.9 \pm 2.1 \mu \mathrm{g} / \mathrm{l}$. However, the threeday value for serum aluminium was extremely and inexplicably high. It was this exceptionally high value of $54.5 \mu \mathrm{g} / 1$ that led us to conduct experiments on ourselves under strictly controlled conditions.

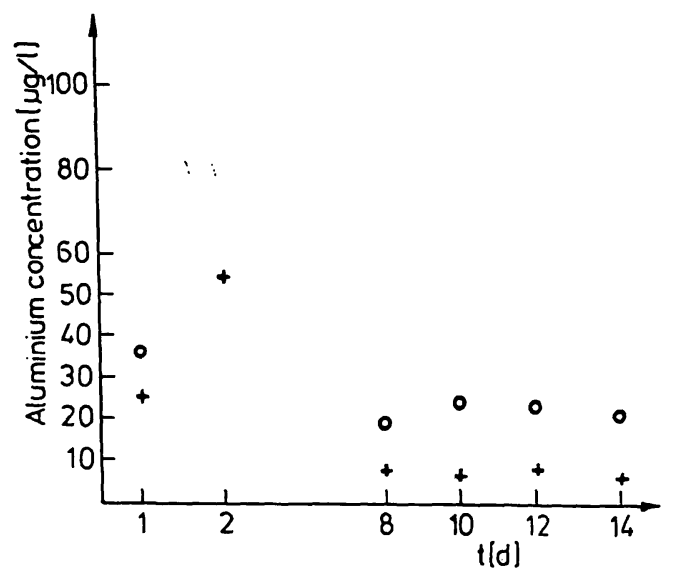

Fig. 1 Aluminium values after Tisacid treatment in 6 patients with duodenal ulcer. The patients were given $4 \times 2$ tablets of Tisacid (an antacid) per day for 14 days. $(+)$ indicates the serum, and $(0)$ the urinary aluminium value of 1 of the 6 patients. The surprisingly high value of $54.5 \mu \mathrm{g} / \mathrm{l}$ on day $3(\mathrm{P}<0.01)$ was due to the inappropriate time of sampling. The serum aluminium concentration of the other 5 patients was $8.9 \pm 2.1 \mu \mathrm{g} / \mathrm{l}$.

Figure 2 summarizes the results of the first of this kind of investigation. At normal, constant serum aluminium values, the urinary aluminium content increased in proportion to the intake of Tisacid. From this we concluded that the absorption of aluminium occurred at $2 \mathrm{~h}$ before sampling. Figure 3 shows the results of the second examination, as well as presenting the dynamics of glucose absorption. As in the case of glucose, the absorption of aluminium reaches its peak $(39 \mu \mathrm{g} / \mathrm{l})$ at $30 \mathrm{~min}$, and after $4 \mathrm{~h}$ it reverts to the initial value $(6.8 \mu \mathrm{g} / \mathrm{l} ; \mathrm{P}<0.05)$ (1). In a separate experiment about $90 \%$ of the aluminium taken in the 4 tablets of Tisacid was recovered in the stools collected over a period of $24 \mathrm{~h}$. Thus, of the orally administered aluminium, as little as $10 \%$ was absorbed.

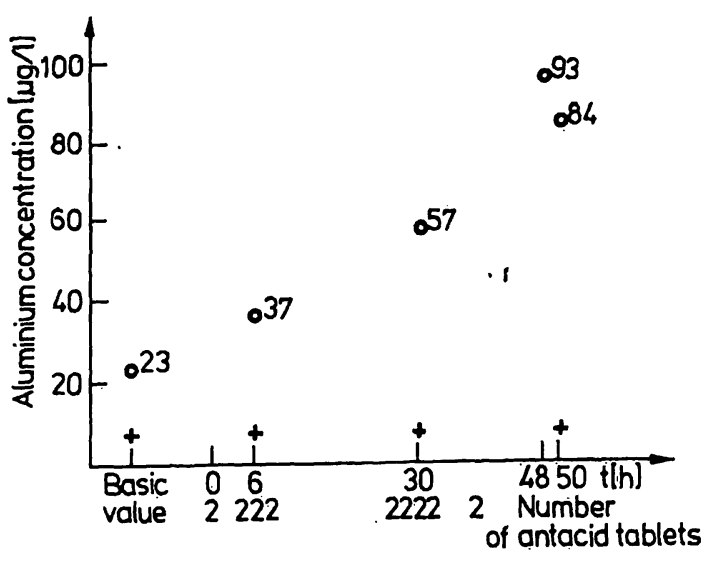

Fig. 2 Changes expressed as $\mu \mathrm{g} / \mathrm{l}$ for serum aluminium $(+)$ and urinary aluminium $(O)$ in response to repeated intake of Tisacid. The data were obtained from the first experiments on the authors. The abscissa shows the number of Tisacid tablets taken, and also the time points of their ingestion and those of blood sampling. In the presence of an unchanged serum aluminium concentration, the value for urinary aluminium increased in proportion to the $\mathrm{Ti}$ sacid taken.

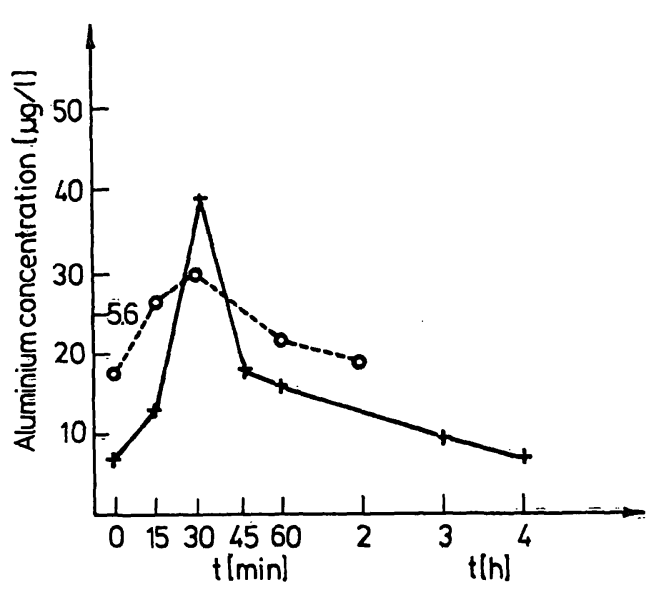

Fig. 3 The kinetics of Tisacid absorption after a single dose of Tisacid and one of glucose. The examination took place in a second experiment on the authors. $(+-+)$ designates the aluminium content in blood samples drawn with a Braun cannula at the times shown on the abscissa; the blood samples were obtained from one of the authors after he had taken 4 tablets of Tisacid $(=232 \mathrm{mg}$ aluminium). The figure also presents the results of a $50 \mathrm{~g}$ glucose tolerance test (O----O).

\section{Discussion}

Our investigations explain why no elevated serum aluminium values have been observed by other workers (see fig. 2). It may be supposed that the exceptionally high value recorded on day 3 (shown in fig. 1) reflects the aluminium concentration of the blood sample drawn at $30 \mathrm{~min}$ after the taking of Tisacid (see fig. 3), in contrast to the aluminium concentrations of the other blood samples obtained earlier or later.

The data on the kinetics of aluminium absorption call attention to the importance of the time point of sam- 
pling, and provide an explanation for the occasionally extremely conflicting results. The occurrence of dialysis dementia in renal patients who have accumulated large amounts of aluminium from the water used for dialysis is well documented (7). However, with normal renal function, as in our case, the limited but rapid absorption and excretion may perhaps explain why the treatment of ulcer patients with aluminium-containing Tisacid is not accompanied with neurological signs and symptoms (8).

\section{Acknowledgement}

Supported by the Hungarian Science Foundation Grant OTKA: $86 / 1991$.

\section{References}

1. Gorsky, J. E., Dietz, A. A., Spencer, H. \& Osis, D. (1979) Metabolic balance of aluminium studied in six men. Clin. Chem. 25 , 1739-1743.

2. Gruskin, A. B. (1988) Aluminium: A pediatric overview. Acta Pediatr. 35, 281-330.

3. Kaehny, W. D., Hegg, A. P. \& Alfrey, A. C. (1977) Gastrointestinal absorption of aluminium from aluminium-containing antacids. N. Engl. J. Med. 296, 1389-1390.

4. Oster, O. (1981) The aluminium content of human serum determined by atomic absorption spectroscopy with a graphite furnacc. Clin. Chim. Acta 114, 53-60.

5. "Aluminium analysis in biological fluids" (1982) International workshop on the role of biological monitoring in the prevention of aluminium toxicity in man. J. Clin. Chem. Clin. Biochem. $20,837-839$.

6. Buratti, M., Caravelli, G., Calzaferri, G. \& Colombi, A. (1984) Determination of aluminium in body fluids by solvent extraction and atomic absorption spectroscopy with clectrothermal atomization. Clin. Chim. Acta 141, 253-259.

7. Alfrey, A. C., LeGendre, G. R. \& Kaehny, W. D. (1977) The dialysis encephalopathy syndrome: Possible aluminium intoxication. N. Engl. J. Med. 294, 184.

8. Meredith, M. \& Blum, A. L. (1989) Antiacides et toxicité de l'aluminium: Une problćmatique réelle ou non? Gastroenterol. Clin. Biol. 13, 441-444.

Prof. Dr. K. Jobst Department of Clinical Chemistry University School of Medicine H-7624 Pécs

Ifjúság u. 13 Hungary 
